\title{
IMPLEMENTASI PEMBELAJARAN KONTEKSTUAL BERBANTUAN MEDIA AUDIO VISUAL UNTUK MENINGKATKAN HASIL BELAJAR SISWA MATA PELAJARAN IPS (EKONOMI) KELAS IX H SMP NEGERI 2 BLAHBATUH TAHUN AJARAN 2017/2018
}

\author{
Gusti Ayu Eka Kharismayani ${ }^{1}$, Lulup Endah Tripalupi $^{2}$, I Nyoman Sujana ${ }^{3}$ \\ Jurusan Pendidikan Ekonomi \\ Universitas Pendidikan Ganesha \\ Singaraja, Indonesia
}

e-mail: ayukkharisma140@gmail.com ${ }^{1}$, Iulup_tripalupi@yahoo.com², sujanatbn@yahoo.com ${ }^{3}$

\begin{abstract}
Abstrak
Penelitian ini bertujuan untuk meningkatkan hasil belajar siswa dengan implementasi pembelajaran kontekstual berbantuan media audio visual, dan mendeskripsikan respon siswa terhadap implementasi pembelajaran kontekstual berbantuan media audio visual pada mata pelajaran IPS (ekonomi) di kelas IX H SMP Negeri 2 Blahbatuh tahun ajaran 2017/2018. Penelitian ini merupakan penelitian tindakan kelas yang dilaksanakan dalam dua siklus dengan tahapan-tahapan setiap siklus meliputi perencanaan, pelaksanaan, observasi/evaluasi, refleksi. Data hasil belajar siswa dikumpulkan melalui tes hasil belajar pada akhir setiap siklus, sedangkan data respon siswa dikumpulkan dengan cara penyebaran angket/kuesioner. Data yang telah terkumpul selanjutnya dianalisis dengan analisis deskriptif. Hasil penelitian ini menunjukkan bahwa implementasi pembelajaran kontekstual berbantuan media audio visual dapat meningkatkan hasil belajar siswa. Hal ini ditunjukkan dengan jumlah siswa yang telah tuntas pada siklus I sebesar $55,6 \%$, sedangkan pada siklus II jumlah siswa yang telah tuntas adalah sebesar $88,9 \%$, dan respons siswa terhadap implementasi pembelajaran kontekstual berbantuan media audio visual diperoleh skor rata-rata sebesar 33,53 dengan kategori positif.
\end{abstract}

Kata kunci: hasil belajar, respons siswa, pembelajaran kontekstual, media audio visual.

\begin{abstract}
This study aims to improve student result with the implementation of contextual learning-aided media audio visual, and describe student's responses the implementation contextual learning assisted audio visual media in social studies (economy) in class IX H "SMP Negeri 2 Blahbatuh" academic year 2017/2018. The research is classroom action research conducted in two cycles with each cycle stagephases include planning, implementation, observation/evaluation, reflection. Student learning outcomes data collected through achievement test at the end of each cycle while student response data collected by questionnares. The data has been collected is then analyzed by using descriptive. The result showed implementation contextual learning assisted audio visual media can improve student learning outcomes. This is indicated by the number of student who have completed the first cycle of $55,6 \%$, while in the second cycle the number of student who have completed amounted to $88,9 \%$, and the response of student to the implementation contextual learning assisted audio visual media obtained average scores average of 33,53 with the positive category.
\end{abstract}

Keywords: learning outcomes, student response, contextual learning audio visual media. 


\section{PENDAHULUAN}

Proses pembelajaran pada hakekatnya adalah suatu proses komunikasi. Komunikasi ini terjadi antara guru sebagai komunikator dan siswa sebagai komunikan. Seringkali terjadi misscommunication antara guru dengan siswa yaitu apa yang dijelaskan oleh guru tidak dapat diterima dengan baik oleh siswa. Oleh karena itu, dalam proses pembelajaran guru perlu menggunakan media pembelajaran. "Media pembelajaran adalah segala sesuatu yang dapat digunakan untuk menyalurkan pesan (bahan pembelajaran) sehingga dapat merangsang perhatian, minat, pikiran, dan perasaan pebelajar (siswa) dalam kegiatan belajar untuk mencapai tujuan pembelajaran" (Tegeh, 2008:4).

Di Sekolah Menengah Pertama (SMP) Negeri 2 Blahbatuh pada saat kegiatan pembelajaran IPS (ekonomi) dilakukan, seringkali terlihat bahwa guru masih menggunakan metode ceramah sehingga suasana belajar di kelas menjadi pasif karena aktivitas belajar masih didominasi oleh guru. Selain itu, pada saat proses pembelajaran guru kurang memanfaatkan media pembelajaran sehingga menyebabkan siswa kurang tertarik terhadap pelajaran IPS (ekonomi) dan menyebabkan siswa tidak serius pada saat pembelajaran.

Kurangnya ketertarikan siswa terhadap pelajaran ekonomi terlihat dari rendahnya hasil belajar siswa khususnya siswa kelas IX H tahun pelajaran 2016/2017 yang berjumlah 36 siswa. Hasil wawancara yang telah dilakukan dengan guru mata pelajaran IImu Pengetahuan Sosial (IPS) serta observasi langsung dan pengamatan ke SMP Negeri 2 Blahbatuh didapatkan hasil belajar siswa kelas IX $\mathrm{H}$ yang tergolong kategori tuntas sebesar 11,1\% (4 orang) dan siswa yang tidak tuntas sebesar $88,9 \%$ (32 orang). Tingkat ketuntasan belajar IPS secara klasikal adalah 11,1\% berada dalam kategori sangat kurang. Jadi, persentase hasil belajar secara klasikal belum memenuhi ketuntasan belajar sebesar $75 \%$, sehingga proses pembelajaran dikatakan belum tuntas. Mengacu pada tuntutan kurikulum, siswa dikatakan tuntas belajar apabila nilai siswa lebih besar atau sama dengan 75. Belum tercapainya ketuntasan hasil belajar IPS (ekonomi) ini (kelas IX H) diduga karena siswa hanya belajar pada saat ulangan umum saja, agar mampu menjawab soal dan yang terpenting tidak remidi. Di samping itu, berdasarkan hasil wawancara dengan siswa kelas IX H SMP Negeri 2 Blahbatuh diperoleh informasi bahwa hasil koreksi terhadap kinerja siswa baik dalam bentuk tugas rumah, ujian blok, maupun ulangan umum hanya diberi tanda benar atau salah tanpa dibahas terlebih dahulu. Bahkan hasil koreksi sering tidak dikembalikan oleh guru. Kondisi seperti itu, membuat siswa merasa sulit memahami konsep yang benar, baik pada tugas, ujian blok, maupun ulangan umum yang telah diberikan.

Berdasarkan permasalahan tersebut, maka dipandang perlu mengatasi problematika siswa dalam meningkatkan hasil belajar siswa dengan mengimplementasikan suatu model pembelajaran yang dapat membantu guru dalam mengefektifkan proses pembelajaran sehingga tidak akan terjadi misscommunication antara siswa dengan guru yaitu dengan mengimplementasikan pembelajaran kontekstual.

Pembelajaran kontekstual adalah pembelajaran yang memungkinkan siswa dari berbagai tingkat, baik mulai dari taman kanak-kanak hingga tingkat SMA untuk menguatkan, memperluas, dan menerapkan pengetahuan serta keterampilan akademik mereka dalam sekolah maupun luar sekolahuntuk memecahkan masalah-masalah dunia nyata maupun masalah yang disimulasikan (Suastra, 2009).

Sedangkan menurut Rusman (2011) Contextual Teaching Learning (CTL) adalah proses belajar mengajar yang erat dengan pengalaman nyata memberi kesempatan dilakukannya pemecahan masalah secara riil/otentik serta latihan dan melakukan tugas. Jadi dapat disimpulkan bahwa pembelajaran kontekstual adalah suatu pembelajaran yang berupaya mengaitkan materi yang dipelajari siswa dengan pengalaman siswa. Pembelajaran 
kontekstual tidak mengharuskan siswa menghafal fakta-fakta, tetapi mendorong siswa mengkontruksi pengetahuan dalam benak siswa sendiri. Nurhadi (2005:5) menyatakan bahwa, "Pembelajaran kontekstual (contectual teaching and learning) adalah konsep belajar yang membantu guru mengaitkan antara materi yang diajarkannya dengan situasi dunia nyata siswa dan mendorong siswa membuat hubungan antara pengetahuan yang dimilikinya dengan penerapannya dalam kehidupan sehari-hari, dengan melibatkan tujuh komponen utama pembelajaran efektif yakni kontruktivisme, bertanya, menemukan, masyarakat belajar, media, dan penilaian sebenarnya". Selain itu Contextual Teaching Learning (CTL) juga menekankan pada berpikir tingkat lebih tinggi, transfer pengetahuan lintas disiplin serta pengumpulan.

Belajar akan lebih bermakna jika anak mengalami apa yang dipelajarinya, bukan mengetahuinya. Proses pembelajaran berlangsung alamiah dalam bentuk kegiatan siswa bekerja dan mengalami bukan mentransfer pengetahuan dari guru ke siswa (Marlina, 2011). Dalam proses belajar mengajar di kelas pembelajaran kontekstual dapat membantu siswa melint makna materi akademik dengan menghubungkan subyek akademik sesuai konteksnya.

Selain model pembelajaran kontekstual, penggunaan media dalam pembelajaran juga sangat penting. Sadiman (2009:7) menjelaskan "media pembelajaran adalah bentuk-bentuk komunikasi baik cetak maupun audio visual'. Media pembelajaran adalah segala sesuatu yang dapat digunakan untuk menyalurkan pesan (bahan pembelajaran) sehingga dapat merangsang perhatian, minat, pikiran, dan perasaan peserta didik dalam kegiatan belajar untuk mencapai tujuan pembelajaran. Dalam kegiatan pembelajaran, media pembelajaran adalah sarana untuk memberikan perangsang bagi pelajar supaya terjadi proses pembelajaran. Media pembelajaran merupakan bagian yang tak terpisahkan dari proses pembelajaran.

Adapun manfaat media pembelajaran dalam proses pembelajaran yaitu media pembelajaran dapat memperjelas penyajian pesan dan informasi sehingga dapat memperlancar dan meningkatkan proses dan hasil belajar, selain itu media pembelajaran juga dapat meningkatkan dan mengarahkan perhatian peserta didik sehingga menimbulkan motivasi belajar, interaksi secara lansung antara peserta didik dengan lingkungannya, dan kemungkinan peserta didik untuk belajar sendiri sesuai kemampuan dan minat serta mengatasi keterbatasan indra, ruang dan waktu.

$\begin{array}{ccc}\text { Media } & \begin{array}{c}\text { pembelajaran } \\ \text { berjalannya }\end{array} \text { proses }\end{array}$ penyampaian materi atau konsep pada diri siswa, pemahaman siswa menjadi lebih baik karena media pembelajaran mampu memberikan gambaran dasar tentang semua hal yang mereka pelajari. Salah satu jenis media pembelajaran adalah media audio visual. "Media audio visual adalah media yang menyajikan materi dengan memanfaatkan indera pendengaran dan penglihatan sebagai alat penyerapan informasi" (Arsyad, 2011:148). Sementara itu Asra (2007: 5) mengungkapkan bahwa media audio visual yaitu media yang dapat dilihat sekaligus di dengar, seperti film bersuara, video, televise, dan sound slide. Media audio visual yang digunakan dalam penelitian ini adalah video. Dengan memanfaatkan media audio visual ini diharapkan siswa menjadi tertarik dan memberikan respon yang positif dalam mengikuti pembelajaran karena disajikan pengalaman yang baru dalam proses pembelajaran.

Dengan mengimplementasikan pembelajaran kontekstual berbantuan media audio visual diharapkan dapat meningkatkan pemahaman siswa terhadap konsep IPS (ekonomi) serta dapat membantu guru untuk menciptakan komunikasi serta suasana pembelajaran yang efektif dan efisien yang berdampak pada peningkatan hasil belajar siswa di kelas.

Berdasarkan uraian di atas, peneliti bermaksud mengatasi permasalahan tersebut melalui penelitian tindakan kelas (classroom action research) dengan mengimplementasikan pembelajaran kontekstual berbantuan media audio visuall 
dalam pembelajaran IPS (ekonomi) di kelas IX H SMP Negeri 2 Blahbatuh. Adapun judul penelitian ini, yaitu implementasi Pembelajaran Kontekstual Berbantuan Media Audio Visual untuk Meningkatkan Hasil Belajar Siswa Mata Pelajaran IPS Kelas IXH SMP Negeri 2 Blahbatuh Tahun Ajaran 2017/2018.

Penelitian ini bertujuan untuk meningkatkan hasil belajar IPS (ekonomi) siswa kelas IXH SMP Negeri 2 Blahbatuh tahun pelajaran 2017/2018 melalui implementasi pembelajaran kontekstual berbantuan media audio visual dan mendeskripsikan respon siswa kelas IX H SMP Negeri 2 Blahbatuh tahun pelajaran 2017/2018 terhadap implementasi pembelajaran kontekstual berbantuan media audio visual dalam pembelajaran IPS (ekonomi).

\section{METODE}

Penelitian ini menggunakan rancangan penelitian tindakan kelas (Classroom Action Reseach) yang bertujuan untuk meningkatkan hasil belajar siswa kelas IX H SMP Negeri 2 Blahbatuh tahun pelajaran 2017/2018 melalui implementasi pembelajaran kontekstual berbantuan media audio visual.

Penelitian ini diawali dari hasil pengamatan langsung dan wawancara peneliti dengan guru mata pelajaran IPS di kelas IX H. Penelitian tindakan kelas ini dilaksanakan secara bersiklus, setiap siklus terdiri dari empat tahapan, yaitu perencanaan tindakan, pelaksanaan tindakan, observasi/evaluasi, refleksi.

Sebelum melakukan penelitian, peneliti mengadakan refleksi awal. Refleksi awal merupakan pengidentifikasian permasalahan serta kendala-kendala baik yang dialami oleh siswa maupun guru. Berdasarkan hasil refleksi awal tersebut maka disusun rencana dan langkahlangkah dalam menerapkan pembelajaran kontekstual berbantuan media audio visual.

Pada setiap akhir siklus peneliti akan memberikan tes untuk mengukur hasil belajar siswa sekaligus peneliti akan menyebarkan angket respon siswa untuk mengetahui respon siswa terhadap implementasi pembelajaran kontekstual berbantuan media audio visual pada pelajaran IPS (ekonomi).

Subjek penelitian ini adalah siswa kelas IX H SMP Negeri 2 Blahbatuh tahun pelajaran 2017/2018 sebanyak 36 orang siswa dan objek penelitian ini adalah implementasi pembelajaran kontekstual berbantuan media audio visual untuk meningkatkan hasil belajar.

Data yang digunakan dalam penelitian ini adalah data primer, dimana data primer merupakan data yang diperoleh peneliti secara langsung (dari tangan pertama). Data yang digunakan berupa data hasil belajar dan data respon siswa serta implementasi pembelajaran kontekstual berbantuan media audio visual untuk meningkatkan hasil belajar siswa.

Jenis Data yang digunakan dalam penelitian ini adalah jenis data kuantitatif, berupa data hasil belajar dan data kualitatif berupa data respon siswa. Jenis data yang digunakan dalam penelitian ini adalah jenis data kuantitatif, berupa data hasil belajar dan data kualitatif berupa data respon siswa. Data yang dikumpulkan dalam penelitian ini adalah data mengenai hasil belajar siswa dan respon siswa terhadap implementasi pembelajaran kontekstual berbantuan media audio visual.

$$
\text { Menurut Arikunto }
$$

"instrument penelitian adalah suatu alat atau fasilitas yang digunakan oleh peneliti dalam mengumpulkan data agar lebih mudah dan hasilnya lebih baik dalam arti lebih cermat, lengkap, dan sistematis sehingga lebih mudah diolah". Pada penelitian ini peneliti menggunakan dua instrument penelitian yaitu tes dan kuesioner. Tes digunakan untuk mengetahui hasil belajar siswa, sedangkan kuesioner digunakan untuk mengetahui respon siswa terhadap implementasi pembelajaran kontekstual berbantuan media audio visual.

Hasil belajar dalam penelitian tindakan kelas ini diperoleh dari hasil tes yang diberikan, berupa tes uraian karena menyesuaikan dengan tujuan dari pembelajaran. Soal uraian diberikan sebanyak 5 soal dengan bobot tiap soal 20 jika memberikan jawaban benar, lengkap, dan banyak memberikan contoh, skor 15 jika memberi jawaban benar dan dengan 
memberikan banyak contoh, skor 10 jika memberikan jawaban benar sesuai konsep, skor 5 jika memberikan jawaban benar tetapi tidak lengkap, dam 0 jika tidak menjawab sama sekali. Dengan demikian Skor Maksimal Ideal (SMI) adalah 100.

Respon siswa terhadap implementasi pembelajaran kontekstual berbantuan media audio visual dikumpulkan dengan angket respon siswa dengan menggunakan skala likert 1 sampai 5 yang terdiri dari pilihan sangat setuju (SS), setuju (S), kurang setuju (KS), tidak setuju (TS) dan sangat tidak setuju (STS).

Analisis terhadap respon siswa dilakukan secara deskriptif, yang terdiri dari 10 item pertanyaan dengan bobot 5 untuk jawaban sangat setuju, 4 untuk jawaban setuju, 3 untuk jawaban ragu-ragu, 2 untuk jawaban tidak setuju dan 1 untuk jawaban sangat tidak setuju. Skor tanggapan maksimal yang diberikan oleh siswa adalah 50 dan skor tanggapan minimal yang dapat diberikan oleh siswa adalah 10.

Analisis data tentang hasil belajar IPS (ekonomi) siswa kelas IX H SMP Negeri 2 Blahbatuh tahun pelajaran 2017/2018 menggunakan metode analisis deskriptif kuantitatif. "metode analisis deskriptif kuantitatif merupakan cara pengolahan data dengan jalan menyusun secara sistematis dalam bentuk angka dan persentase mengenai suatu objek yang diteliti, sehingga diperoleh kesimpulan umum" (Agung, 2005:60).

Data hasil belajar siswa didapatkan setelah diimplementasikan pembelajaran kontekstual berbantuan media audio visual dapat dihitung dengan menghitung skor rata-rata kelas. Rumus yang digunakan

$$
\bar{X}=\Sigma X / N
$$

Keterangan:

$\bar{X}=$ rata-rata skor respon siswa

$\sum X=$ jumlah seluruh skor respon siswa

$\mathrm{N}=$ jumlah siswa

Data rata-rata hasil belajar siswa kemudian dikonversikan seperti tabel 1 untuk mengetahui kategori nilai mata pelajaran IPS (ekonomi) SMP Negeri 2 Blahbatuh. Kriteria Ketuntasan Minimal (KKM) SMP Negeri 2 Blahbatuh dalam mata pelajaran IPS (ekonomi) adalah 75 sehingga siswa dikatakan tuntas jika mencapai nilai hasil belajar dengan kategori baik dan amat baik.

Tabel 1. Konversi Nilai Mata Pelajaran IPS (Ekonomi) SMP Negeri 2 Blahbatuh

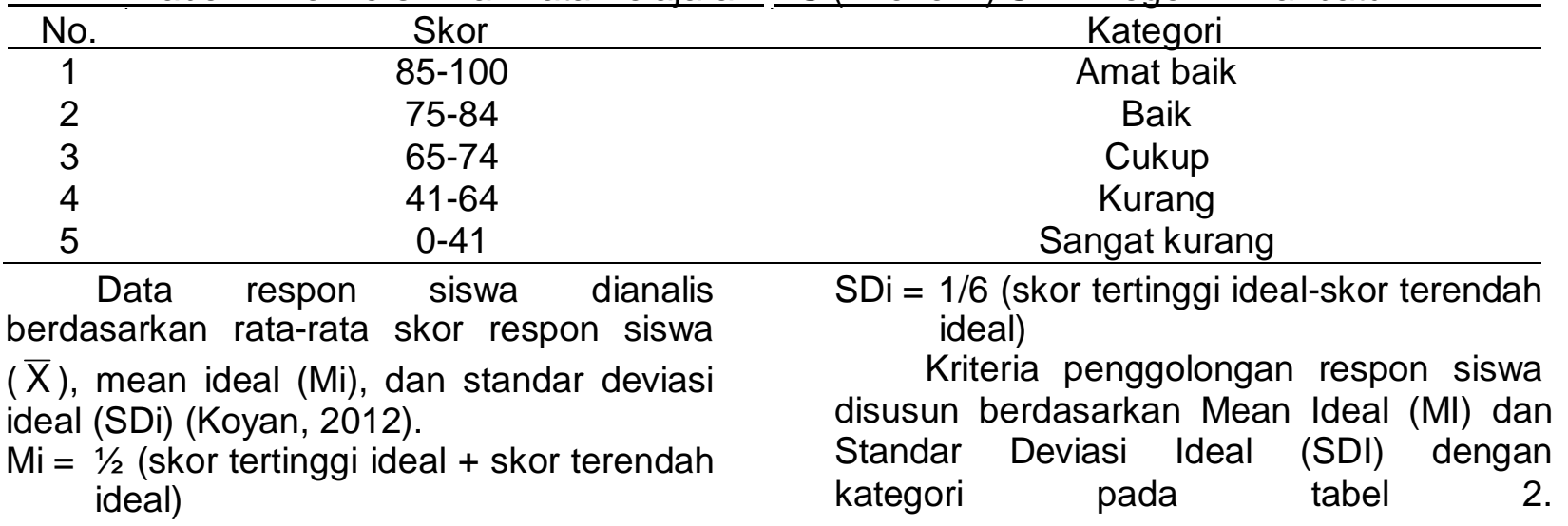

Tabel 2. Kriteria Penggolongan Tingkat Respon Siswa

\begin{tabular}{cc}
\hline Kriteria & Kategori \\
\hline$M_{i}+1,5 S D_{i} \leq \bar{X} \leq M_{i}+3,0 S D_{i}$ & Sangat positif \\
$M_{i}+0,5 S D i \leq \bar{X}<M i+1,5 S D_{i}$ & Positif \\
$M_{i}-0,5 S D i \leq \bar{X}<M i+0,5 S D_{i}$ & Cukup positif \\
$M_{i}-1,5 S D_{i} \leq \bar{X}<M_{i}-0,5 S D_{i}$ & Kurang positif \\
$M_{i}-3,0 S D_{i} \leq \bar{X}<M_{i}-1,5 S D_{i}$ & Sangat kurang positif
\end{tabular}

(Koyan, 2012) 
Hasil yang diperoleh melalui kuesioner tersebut dipresentasikan dengan skor maksimal ideal 50 dan skor minimal ideal 10, Mean ideal (Mi) adalah sebesar 1/2 $x(50+10)=30$. Standar deviasi ideal (SDi) sebesar $1 / 6 \times(50-10)=6,7$. Jadi, dapat ditentukan kategori respon siswa melalui kriteria seperti tampak pada tabel 3 .

Tabel 3. Kriteria Penggolongan Respon Siswa

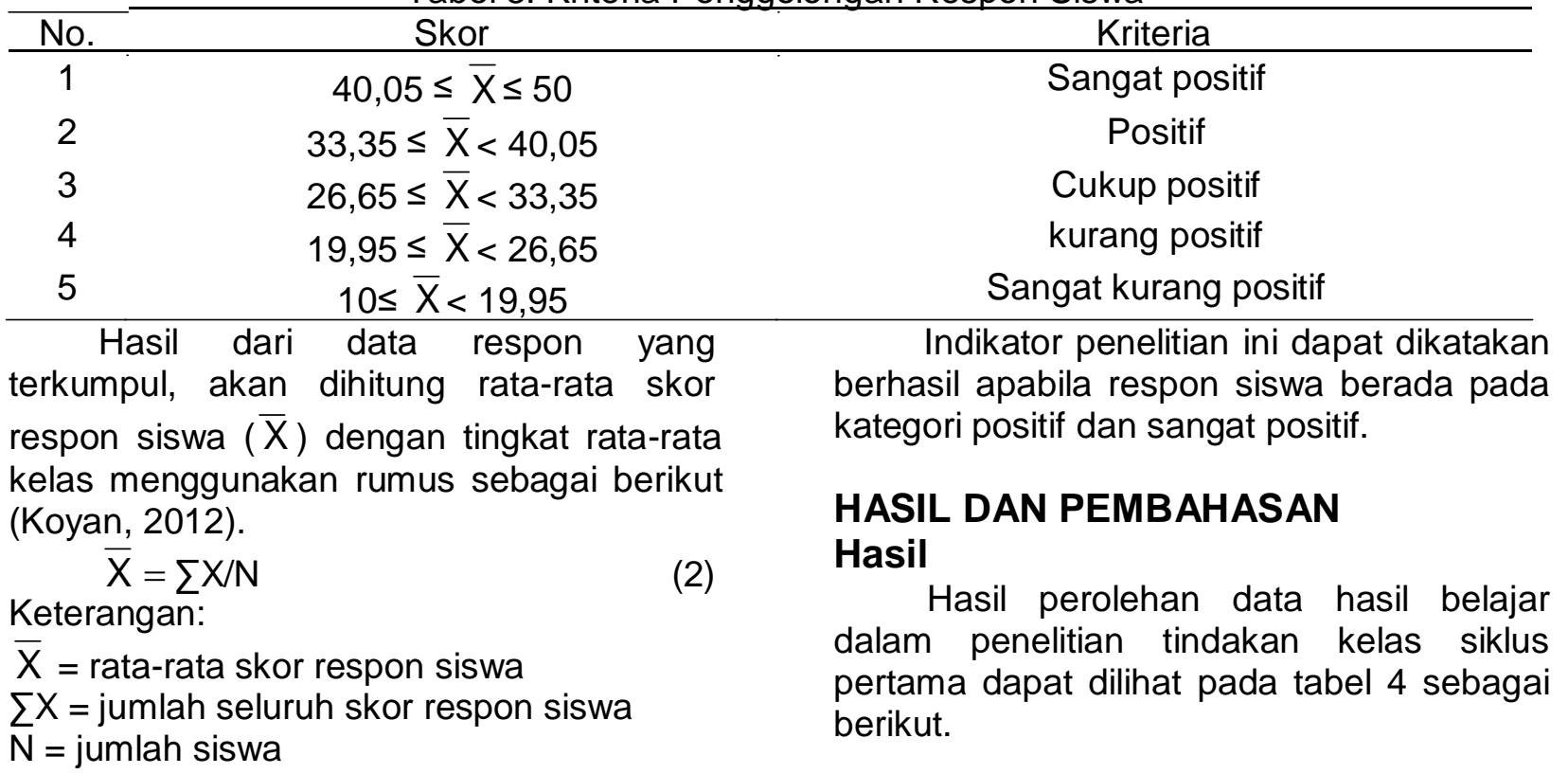

Tabel 4. Data Hasil Belajar Siswa Siklus I

\begin{tabular}{cccccc}
\cline { 3 - 5 } No. & Rentang Skor & Jumlah Siswa & Persentase $(\%)$ & Kategori & Keterangan \\
\hline 1 & $85-100$ & 1 Orang & $2.8 \%$ & Sangat Baik & 20 siswa $(55.6 \%)$ \\
2 & $75-84$ & 19 Orang & $52.8 \%$ & Baik & Tuntas \\
3 & $65-74$ & 9 Orang & $25 \%$ & Cukup & 16 siswa \\
4 & $41-64$ & 7 Orang & $19.4 \%$ & Kurang & $(44.4 \%)$ \\
5 & $0-40$ & - & - & Sangat Kurang & Tidak Tuntas \\
& Total & 36 Orang & 100 & & \\
\hline
\end{tabular}

Berdasarkan pada tabel 4 dapat ditunjukkan bahwa hasil belajar IPS (ekonomi) Siklus I pada siswa kelas IX H pada materi yang terdiri dari sejarah uang, pengertian uang, syarat-syarat suatu uang, fungsi uang, jenis-jenis uang, nilai uang, nilai kurs. Berdasarkan pelaksanaan yang telah dilakukan oleh peneliti pada siklus I dengan jumlah siswa 36 orang, menunjukkan bahwa hasil belajarnya berada pada kategori sangat baik sebanyak 1 orang $(2.8 \%)$, kategori baik sebanyak 19 orang $(52.8 \%)$, kategori cukup sebanyak 9 orang (25\%), kategori kurang sebanyak 7 orang $(19.4 \%)$, kategori sangat kurang baik tidak ada (0\%). Jumlah siswa tuntas pada hasil belajar pertemuan siklus I sebesar 20 orang dengan jumlah siswa $n=36$ orang.

Dalam pelaksanaan penelitian pada siklus I, terdapat beberapa kendala-kendala dalam implementasi pembelajaran kontekstual berbantuan media audio visual. Kendala-kendala atau permasalahan tersebut adalah masih terdapat beberapa siswa yang suka bermain-main dan mengganggu temannya saat kegiatan diskusi dilakukan, masih ada beberapa siswa yang keluar masuk kelas saat pemutaran video pembelajaran berlangsung, siswa masih cenderung ribut saat pemutaran video sehingga suara video sulit untuk di dengar oleh siswa lainnya, guru kekurangan waktu dalam mengajar, 
hal ini disebabkan oleh beberapa siswa yang senang membuat keributan dan suka mengganggu temannya pada saat proses pembelajaran yang menyebabkan konsentrasi temannya terganggu sehingga hal ini dapat menghambat kegiatan pembelajaran dalam efisiensi waktu.

Berdasarkan kendala-kendala tersebut, tindakan perbaikan yang dilakukan adalah yang pertama guru memberikan penjelasan kepada siswa yang masih bermain-main dan mengganggu temannya saat kegiatan diskusi, untuk lebih serius dalam kegiatan kelompok yang kedua guru menegaskan kepada siswa agar tidak keluar masuk kelas saat pemutaran video berlangsung, hal ini dilakukan agar siswa lainnya dapat menyimak video dengan baik, yang ketiga guru menegaskan kepada siswa unruk tidak ribut saat pemutaran video berlangsung agar tidak mengganggu konsentrasi siswa yang lain dan yang terakhir guru akan memberikan teguran terhadap siswa yang mengganggu temannya sehingga proses pembelajaran dapat berjalan sesuai dengan harapan.

Hasil refleksi siklus I dipergunakan sebagai bahan pertimbangan untuk siklus II. Kegiatan refleksi dilanjutkan dengan revisi perencanaan untuk memperbaiki tindakan pada siklus I yang akan diimplementasikan pada siklus II. Hasil perolehan data hasil belajar dalam penelitian tindakan kelas siklus kedua dapat dilihat pada tabel 5 sebagai berikut.

Tabel 5. Data Hasil Belajar Siswa Siklus II

\begin{tabular}{|c|c|c|c|c|c|}
\hline No. & Rentang Skor & Jumlah Siswa & Persentase $(\%)$ & Kategori & Keterangan \\
\hline 1 & $85-100$ & 12 orang & $33.3 \%$ & Amat Baik & 32 siswa $(88.9 \%)$ \\
\hline 2 & $75-84$ & 20orang & $55.5 \%$ & Baik & Tuntas \\
\hline 3 & $65-74$ & 2 orang & $5.6 \%$ & Cukup & \\
\hline 4 & $41-64$ & 2 orang & $5.6 \%$ & Kurang & 4 siswa $(11.1 \%)$ \\
\hline 5 & $0-40$ & & - & Sangat Kurang & I Iuan I uillas \\
\hline & Total & 36 Orang & 100 & & \\
\hline
\end{tabular}

Berdasarkan pada tabel di atas, dapat dijelaskan sebagai berikut. Hasil belajar IPS (ekonomi) siklus II pada siswa kelas IX H pada materi yang terdiri dari pengertian bank, asas perbankan di Indonesia, fungsi utama bank, tujuan perbankan di Indonesia, jenis-jenis bank, produk-produk bank, lembaga keuangan bukan bank, jenis-jenis lembaga keuangan bukan bank. Berdasarkan pelaksanaan yang telah dilakukan oleh peneliti pada siklus II dengan jumlah siswa 36 orang, menunjukkan bahwa hasil belajarnya berada pada kategori amat baik sebanyak 12 orang $(33.3 \%)$, kategori baik sebanyak 20 orang $(55.5 \%)$, kategori cukup sebanyak 2 orang $(5.6 \%)$, kategori kurang sebanyak 2 orang $(5.6 \%)$, kategori sangat kurangtidak ada $(0 \%)$. Jumlah siswa tuntas pada hasil belajar pertemuan siklus II sebesar 32 orang dengan jumlah siswa $n=36$ orang.

Setelah diadakan perbaikan pada siklus II, tampak terjadi peningkatan pada hasil belajar siswa. Dalam pelaksanaan tindakan pada siklus II, dapat diamati halhal berkaitan dengan kegiatan belajar mengajar dengan implementasi pembelajaran kontekstual berbantuan media audio visual yaitu pada pelaksanaan tindakan siklus II, siswa sudah mampu mengikuti pembelajaran, siswa sudah mulai mendengarkan arahan guru saat proses pembelajaran, dan mulai meninggalkan kebiasaannya bermain-main, sehingga waktu belajar dapat dimanfaatkan secara lebih efisien, semua siswa tampak menunjukkan antusias mereka saat proses pembelajaran, situasi belajar siswa sudah kondusif jika dibandingkan dengan pertemuan-pertemuan sebelumnya pada siklus I.

Berdasarkan hasil analisis dari angket respon siswa yang dibagikan, maka adapun kategori penggolongan respon siswa terhadap implementasi pembelajaran kontekstual berbantuan media audio visual pada pelajara IPS (ekonomi) yang tertuang dalam tabel 6 berikut. 
Tabel 6. Kategori Penggolongan Respon Siswa

\begin{tabular}{ccccc}
\hline No. & Kriteria & Jumlah Siswa & Persentase & Kategori \\
\hline 1 & $40,05 \leq X \leq 50$ & 0 & 0 & Sangat Positif \\
2 & $33,35 \leq X<40,05$ & 19 & $52,8 \%$ & Positif \\
3 & $26,65 \leq X<33,35$ & 17 & $47,2 \%$ & Cukup Positif \\
4 & $19,95 \leq X<26,65$ & 0 & 0 & Kurang Positif \\
5 & $10 \leq X<19,95$ & 0 & 0 & Sangat Kurang Positif \\
& Jumlah & 36 & $100 \%$ & \\
\hline
\end{tabular}

Berdasarkan tabel 6 di atas dapat disimpilkan bahwa, respon siswa yang berada pada kategori sangat positif tidak ada $(0 \%)$, kategori positif sebanyak 19 orang (52,8\%), kategori cukup positif sebanyak 17 orang $(47,8 \%)$, kategorii kurang positif sebanyak tidak ada $(0 \%)$, dan sangat kurang positif tidak ada (0\%). Berdasarkan analisis data, diketahui ratarata skor respon siswa adalah 33,53. Dengan demikian, rata-rata skor 33,53 bila di konversikan ke dalam kategori penggolongan respon siswa berada pada rentang $33,35 \leq \bar{X}<40,05$ atau berada dalam kategori positif.

\section{Pembahasan}

Berdasarkan hasil penelitian yang dilaksanakan dalam dua siklus, menunjukkan telah terjadi peningkatan hasil belajar siswa melalui implementasi pembelajaran kontekstual berbantuan media audio visual. Hal ini ditunjukkan dengan adanya peningkatan hasil belajar siswa, yang dapat dilihat dari adanya kenaikan nilai rata-rata kelas sebesar 9,61 dari 64 pada observasi awal menjadi 73,61 pada akhir siklus I. Dari segi ketuntasan belajar juga terjadi peningkatan yaitu meningkat sebesar $44,4 \%$ dari $11,1 \%$ pada observasi awal menjadi 55,5\%.

Pada siklus I peningkatan hasil belajar dicapai melalui variasi kegiatan pembelajaran seperti guru membimbing siswa yang pada awalnya mengalami kesulitan dalam memahami materi, memberikan pernyataan arahan untuk menumbuhkan pemahaman siswa terhadap materi dan memberikan penghargaan sebagai timbal balik dari kegiatan siswa serta hasil yang dicapai siswa akan membuat lebih bersemangat untuk belajar.
Peningkatan hasil belajar siswa juga dicapai pada siklus II. Hasil belajar pada siklus II juga meningkat yang ditandai dengan kenaikan nilai rata-rata siswa sebesar 7,45 dari 73,61 pada siklus I menjadi 81,06 pada siklus II. Ketuntasan belajar siswa juga meningkat sebesar $27 \%$ dari $55,6 \%$ pada siklus I menjadi $88,9 \%$ pada siklus II. Dari hal tersebut dapat dilihat terjadi peningkatan yang cukup tinggi pada hasil belajar siswa.

Dengan implementasi pembelajaran kontekstual berbantuan media audio visual menunjukkan terjadi peningkatan hasil belajar siswa. Hal ini ditunjukkan dengan peningkatan skor rata-rata hasil belajar siswa pada siklus I sampai dengan siklus II dengan rata-rata kenaikan sebesar 7,45. Walaupun dari siklus I ke siklus II hasil belajar siswa mengalami peningkatan namun pada proses pembelajaran siklus I masih terdapat kendala dalam proses pembelajaran. Kendala tersebut kemudian ditindaklanjuti dengan mencari alternatif pemecahan untuk melaksanakan siklus yang ke II. Pada siklus II hasil belajar siswa sudah mengalami peningkatan, siswa yang sebelumnya kesusahan menjawab soal, sudah mulai lancar dalam menjawab soalsoal yang diberikan,mau menyimak video pembelajaran dengan tertib, menanggapi jawaban temannya dan bertanya kepada guru apabila ada yang kurang dimengerti.

Analisis respon siswa menunjukkan bahwa rata-rata skor respon siswa adalah sebesar 33,53. Berdasarkan kriteria penggolongan respon siswa yang telah ditetapkan maka respon siswa kelas IX H SMP Negeri 2 Blahbatuh terhadap implementasi pembelajaran kontekstual berbantuan media audio visual tergolong kategori positif. Hal ini berarti bahwa siswa 
senang dan tertarik dengan pembelajaran kontekstual berbantuan media audio visual dan siswa memandang bahwa pembelajaran kontekstual berbantuan media audio visual cocok diterapkan dalam pembelajaran IPS (ekonomi). Dengan meningkatnya hasil belajar IPS (ekonomi) siswa kelas IX H SMP Negeri 2 Blahbatuh maka dapat dikatakan bahwa Implementasi Pembelajaran Kontekstual Berbantuan Media Audio Visual dapat Meningkatkan Hasil Belajar IPS (ekonomi) Siswa Kelas IX H SMP Negeri 2 Blahbatuh tahun ajaran 2017/2018 serta dapat menumbuhkan respon positif siswa.

Dari hasil analisis data yang dilakukan maka implementasi pembelajaran kontekstual berbantuan media audio visual pada mata pelajaran IPS (ekonomi) memberikan suatu indikasi keberhasilan dalam upaya meningkatkan hasil belajar siswa. Peningkatan hasil belajar dengan implementasi pembelajaran kontekstual berbantuan media audio visual sejalan dengan pendapat Nurhadi (2005:5) yang menyatakan bahwa, pembelajaran kontekstual (contectual teaching and learning) adalah konsep belajar yang membantu guru mengaitkan antara materi yang diajarkan dengan situasi dunia nyata siswa dan mendorong siswa membuat hubungan antara pengetahuan yang dimilikinya dengan penerapannya dalam kehidupan sehari-hari, dengan melibatkan tujuh komponen utama pembelajaran efektif yakni kontruktivisme, bertanya, menemukan, masyarakat belajar, media, dan penilaian sebenarnya.

Penggunaan media audio visual dalam proses pembelajaran sangat membantu guru dalam proses pembelajaran dimana seperti yang dikemukan oleh Asyhar (2012:8) media pembelajaran merupakan segala sesuatu yang dapaat menyampaikan atau menyalurkan pesan dari sumber secara terencana, sehingga terjadi lingkungan belajar yang kondusif dimana penerimanya (siswa) dapat melakukan proses belajar secara efisien dan efektif.

Dengan demikian implementasi pembelajaran kontekstual berbantuan media audio visual pada mata pelajaran IPS (ekonomi) dalam proses pembelajaran akan membuat kegiatan pembelajaran berlangsung secara tepat guna dan berdaya guna sehingga dapat meningkatkan hasil belajar siswa. Implementasi pembelajaran kontekstual berbantuan media audio visual tidak hanya sekedar memberikan informasi tapi juga membantu kesulitan belajar siswa sehingga guru dengan siswa berinteraksi secara laangsung.

\section{SIMPULAN DAN SARAN Simpulan}

Berdasarkan hasil analisis dan pembahasan pada bab IV, maka dapat ditarik simpulan yaitu implementasi pembelajaran kontekstual berbantua media audio visual dapat meningkatkan hasil belajar siswa dalam pembelajaran IPS (ekonomi) siswa kelas IX H SMP Negeri 2 Blahbatuh. Hal ini dapat dilihat dari tingkat ketuntasan siswa pada observasi awal hingga siklus I dan II. Pada Observasi Awal tingkat ketuntasan siswa sebanyak 4 siswa $(11,1 \%)$ dan pada siklus I mengalami peningkatan sebesar 16 siswa $(44,4 \%)$ menjadi 20 siswa $(55,5 \%)$ dan pada siklus II mengalami peningkatan sebesar 12 siswa $(33,3 \%)$ menjadi 32 siswa $(88,9 \%)$, dengan demikian dapat disimpulkan bahwa implementasi pembelajaran kontekstual berbantuan media audio visual dapat meningkatkan hasil belajar siswa. Dan dengan implementasi pembelajaran kontekstual berbantuan media audio visual siswa memberikan respon positif dengan rata-rata skor respon siswa sebesar 33,53.

\section{Saran}

Adapun saran-saran yang disampaikan adalah yang pertama kepada guru mata pelajaran IPS agar dapat mengimplementasikan pembelajaran kontekstual berbantuan media audio visual dalam proses pembelajaran, karena pembelajaran kontekstual berbantuan media audio visual ini dapat meningkatkan hasil belajar siswa serta memperluas pemahaman siswa terhadap mata pelajaran IPS (ekonomi), yang kedua diharapkan saat mengimplementasikan pembelajaran kontekstual berbantuan media audio visual dalam proses pembelajaran guru memperhatikan setiap langkah 
pembelajaran yang ada dalam pembelajaran ini sehingga pembelajaran ini dapat berjalan dengan baik, dan bagi calon peneliti yang berminat untuk meneliti lebih lanjut dengan menggunakan pembelajaran kontekstual berbantuan media audio visual agar memperhatikan kendala-kendala yang dihadapi peneliti sebagai bahan pertimbangan untuk perbaikan dan penyempurnaan pelaksanaan penelitian berikutnya.

\section{DAFTAR PUSTAKA}

Agung, A. A. Gede. 2010. Penilaian Hasil Proses Belajar Mengajar. Bandung: PT Remaja Rosdakarya Offset.

Arikunto, Suharsimi. 2003. Prosedur Penelitian, Suatu Praktek. Jakarta: Bina Aksara.

Arsyad, A. 2002. Media Pembelajaran. Jakarta: Raja Grafindo Persada.

Asra \& Sumiati. 2007. Metode Pembelajaran Pendekatan Individual. Bandung: Rancaekek Kencana.

Asyhar, Rayanda. 2012. Kreatif Mengembangkan Media Pembelajaran. Jakarta: Gaung Persada (GP) Press Jakarta.

Koyan, I Wayan. 2012. Statistik Pendidikan: Teknik Analisis Data Kuantitatif. Singaraja: Universitas Pendidikan Ganesha Perss.

Marlina. 2011. Model Contextual Teaching And Learning (CTL) Pada Perkuliahan Dasar Rias (Tata Kecantikan Wajah Dan Rambut) Untuk Meningkatkan Kreativitas Mahasiswa. Jurnal Penelitian Pendidikan, 12(1), 13-23.

Nurhadi, 2005. Kurikulum 2004 (pertanyaan dan jawaban). Jakarta: Penerbit PT. Grasindo.

Rusman. 2011. Model Pembelajaran Mengembangkan Profesionalisme Guru. Jakarta: PT. Raja Grafindo Persada.

Sardiman. 2009. Interaksi dan Motivasi Belajar-Mengajar. Jakarta: PT. Raja Grafindo Persada.
Suastra, I W. 2009. Pembelajaran Sains Terkini. Singaraja: Universitas Pendidikan Ganesha.

Tegeh, I Made. 2008. Media Pembelajaran. Singaraja: Institut Keguruan dan ilmu Pendidikan Negeri Singaraja. 